\title{
Preliminary factor analysis of the O'Kelly Women Beliefs Scale in a US sample*
}

\author{
Análisis factorial preliminar de la O'Kelly Women
} Beliefs Scale en una muestra estadounidense

Recibido: febrero 14 de 2010 | Revisado: agosto 10 de 2010 | Aceptado: noviembre 11 de 2010

\author{
Arturo Heman Contreras ** \\ Instituto Mexicano de Psicoterapia \\ Cognitivo Conductual S.C., México \\ LEONOR LEGA ${ }^{* * *}$ \\ JOSHUA FEINBERG \\ ERIKA QUEDDING \\ Saint Peter's College, New Jersey, USA \\ MONICA O’KeLLY \\ Monash University, Victoria, Australia \\ MARK J. FRIEDMAN \\ Montclair State University, New Jersey, USA
}

SICI: 1697-9267(201206)11:2<611:AFPOWB>2.0.TX;2-T

Para citar este artículo. Heman, A., Lega, L., Feinberg, J., Quedding, E., O'Kelly, M., \& Friedman, M. J. (2012). Preliminary factor analysis of the O'Kelly Women Beliefs Scale in a US sample. Universitas Psychologica, 11(2), 611-617.

* Artículo de investigación.

** Director, Instituto Mexicano de Psicoterapia Cognitivo-Conductual.E-mail: aheman@prodigy.net.mx ResearcherID; Heman, A. F-4264-2012.

**** Professor of Psychology, Saint Peter's College. E-mail:1lega@spc.edu
A B S T R A C T

Using a Rational Emotive Behavior Therapy framework, the O'Kelly Women Beliefs Scale (O'Kelly, in press) was originally constructed in Australia to measure sex-role beliefs women may develop through sex-role stereotyping. Factor analysis of the 92 original items showed that 64 items loaded into a single component that accounted for $18.2 \%$ of the variance in a sample of 974 Australian women. The present exploratory study examined the psychometric properties of the OWBS in a sample of 202 women born and living in the US. A varimax rotation with cutoff eigenvalues of 3 , showed that 37 items loaded into 3 components which accounted for $58.48 \%$ of the variance. The items were subsequently grouped into two factors: Irrationality, with a total of 27 items was created by merging component 1 and 3 (Pearson's $r=0.8$ between them), and Rationality, with the 10 items from component 2. Analyses indicated a Cronbach's alpha of 0.91 for Factor 1, and a Cronbach's alpha 0.74 for Factor 2. Results indicate that this version of the instrument may be used to evaluate both the rational and irrational content of sex-role beliefs of women born in the US.

Key words authors

Irrational belief, factor analysis, rational emotive behavioral therapy, attitudes.

Key words plus

Psychometry, psychological tests, quantitative research.

\section{RES U MEN}

En el contexto de la Terapia Racional Emotivo-Conductual, se desarrolló la O'Kelly Women Beliefs Scale (OWBS) construida originalmente en Australia, para evaluar las creencias sobre el rol sexual que las mujeres pueden desarrollar como estereotipo. En una muestra de 974 mujeres australianas, el análisis factorial de los 92 reactivos originales mostró que 64 de ellos cargaron en un solo componente que explica el $18.2 \%$ de la varianza total. El objetivo del presente estudio exploratorio es determinar la estructura factorial del OWBS, en 202 mujeres nacidas en E.E. U.U. La rotación Varimax con punto de corte de autovalor en 3, arrojó que 37 ítems cargan en tres componentes que explican el $58.48 \%$ de la varianza total. Los reactivos se agruparon en dos factores: Irracionalidad, con un total de 27 reactivos que se integraron en los componentes 1 y $3(r=0.8)$ y Racionalidad, con 10 
reactivos integrados en el componente 2. El alfa de Cronbach fue de 0.91 para el Factor 1 y de 0.74 para el Factor 2. Los resultados indican que esta versión del instrumento puede ser usada para evaluar tanto el contenido racional como el irracional de las creencias sobre el rol sexual de las mujeres nacidas en E.E. U.U.

Palabras clave autores

Creencias irracionales, análisis factorial, terapia comportamental emocional-emotiva, actitudes.

Palabras clave descriptores

Psicometría, pruebas psicológicas, investigación cuantitativa.

The purpose of this study was to investigate the psychometric characteristics of the O'Kelly Women Beliefs Scale (OWBS) in a sample of women born and living in the US. Originally developed in Australia (O'Kelly, in press) the OWBS measures specific sex-role beliefs in women.

The OWBS was developed based on the irrational demands that women place on themselves as outlined by Wolfe and Naimark (1991) as a alternative to the much used Bem Sex Role Inventory ([BSRI], Bem, 1981), which has attracted considerable criticism (O'Kelly, in press). Following suggestions by critics of the BSRI (Locksley \& Colton, 1979), the OWBS was developed within a new theoretical perspective regarding formal and structural features of cognitive organization where behavior rules would begin with concepts of more immediate relevance for self perception and self-direction rather than global psychological constructs related to sex role orientation as in the BSRI.

The OWBS is a self-report measure which may have some limitation in reflecting an individual's true irrational beliefs. Ellis (1973) suggested that irrational beliefs are just below the top level of consciousness and that the traditional wording of beliefs in Rational Emotive Behavior Therapy (REBT) terminology may not lead a respondent to interpret a phrase in the same way as the rational-emotive behavior therapist writing the item would. Given this limitation, however, Ellis (1989) believed that self report measures can still be a fairly good measures of irrationality. Self report measures of beliefs have been used with meaningful results by others (Bernard, 1990; Burgess, 1986; Robin, DiGiuseppe, \& Naimark, 1990). Furthermore, they seem to be useful tools in cross-cultural studies (Lega \& Ellis, 2001) designed to gather data on the beliefs of individuals across different ethno-cultural backgrounds.

A number of steps were involved in the development of the initial O'Kelly Women's Belief Scales (OWBS). Twenty-three demands that women place on themselves were extracted from those mentioned by Wolfe and Naimark (1991) to form the basis of the OWBS. The Demands were then rewritten to reflect the four irrational thought processes REBT centers on. In addition to the Demands or "should be's" the statements were written to reflect Awfulizing, Low Frustration Tolerance, and Generalized Rating, in this case Negative Self Rating (Burgess, 1990; Campbell, 1985; Ellis, 1977, 1984). One third of the items were rewritten in a rational form to increase the scale's ability to discriminate (DiGiuseppe, Robin, Leaf, \& Gormon, 1989) and to avoid response bias (Judd, Smith, \& Kiddler, 1991). The items were then randomly arranged. Subjects were asked to indicate the extent of their agreement with each item on a five point Likert-type scale, ranging from 1-Strong disagreement to 5- Strong agreement. For the irrational items the higher the score, the higher the adherence to traditional beliefs.

The original study developing the OWBS (O'Kelly, in press) explored the beliefs of women working in a large, general, multi-site, teaching hospital in suburban Melbourne, Australia. The women had comparable work conditions and were in a variety of occupational categories such as cleaners, kitchen staff, clerical staff, nurses, health professionals and in managerial roles. Questionnaires were sent to 2560 women. Of these 974 (38\%) were returned with all or part of the questionnaire completed.

Principal component analysis (SPSS, 1988) on the data from the 974 Australian subjects for the 92 items (61 "irrational" items and 31 "rational" items) showed a single component labeled "General Traditional Beliefs". This factor included 64 of the 92 items, and accounted for $18.2 \%$ of the variance. A Cronbach's alpha of 0.95 indicated high internal consistency.

These results were consistent with the REBT model. They were all sources of irrationality, and included the irrational thought processes of Awfulz- 
ing, Low Frustration Tolerance, and Negative Self Rating which are derived from one single factor; the musts and shoulds, or absolutistic, rigid demands in the thought process of the individual.

Three tests were chosen to assess the concurrent validity of the OWBS (O'Kelly, in press): The BSRI short form (Bem, 1981), the short version (25 items) of the Attitudes toward Women Scale ([AWS], Spence, Helmreich, \& Stapp, 1973), and The Tradition-Egalitarian Sex Role Scale ([TESR], Larsen \& Long, 1988). Results showed that none of the OWBS subscales were correlated with the Femininity scale of the BSRI, and that the OWBS was negatively correlated with the ATW and TESR scales as expected. The results also suggest that the OWBS, the AWS and the TESR measuring a similar underlying concept or construct, a construct that the BSRI does not measure.

Although Australia and the US are Englishspeaking countries, Matsumoto (2000) suggests that establishing ethno-cultural equivalence in meaning and measurement of concepts is a necessary step in making valid multi-national comparisons.

Brislin (1973) proposes the use of the Back-Translation Method for equivalency of meaning of the concepts, where adaptations were made in the wording of the OWBS from "Australian" English to "US" English (i.e. the spelling of words like "behaviour" vs. "behavior") by two researchers who familiar with the regional uses of the language in both countries.

The use of the same procedure in the statistical analysis of the data, a principal component analysis (SPSS), may be utilized for equivalency in the measurement of the concepts in the Australian sample and in a sample of women in the US.

\section{Method}

\section{Participants}

The sample consisted of 202 women born and living in the US, as were their parents and their grandparents. Their ages ranged from 17 to 69 years, with an average age of $M=32.6$ years and a standard deviation of $S D=15.04$.

\section{Instrument}

The "US version" of the original 92 items of the OWBS, with its five-point Likert-type scale, ranging from $1=$ Strong disagreement to $5=$ Strong agreement to indicate the extent of the respondent's agreement with each item, was individually administered to the US sample.

\section{Procedure}

The US version of the OWBS, were distributed to female students in a number of Psychology courses in several northeast liberal arts colleges. A factor analysis (SPSS, version 11) was used on the data (Rotation Method: Varimax with Kaiser Normalization, Eigen Value of greater than 3; Extraction Method: Principal Component Analysis with a minimum of 0.4). In addition, Cronbach's alphas were used as reliability statistics for the extracted factors.

\section{Results}

\section{Construct Validity}

The data was initially examined to make sure it met the requirements for factor analysis: None of the items had a kurtosis larger than 2, and all the items included showed a response pattern where the variance was spread out among the five response options, and where none of them had $75 \%$ or higher of the responses in any given option.

Factor analysis was then used to explore if the US data would show factors equivalent to those obtained in the original Australian study. Items were selected on the basis of good convergent validity (extraction values of 4 and above), and discriminant validity (if an item loaded in two factors, the difference in their extraction values was 0.15 or above).

Bartlett's Test of sphericity was significant, and Kaiser-Meyer-Olkin measure of sampling adequacy was very good $(\mathrm{KMO}=0.935)$, which further supported the selection of factor analysis as the appropriate statistical method for this study.

After a principal components analysis using varimax rotation, and a careful examination of 
items' content to try to establish the correct labels, the first 3 factors which accounted for $58.48 \%$ of the variance were selected. Of the original 92 items, 37 were selected on the basis of extraction values of 0.4 or above in any given factor, which corresponds in the US sample to $40.21 \%$ of the items in the original Australian instrument.

Table 1 shows the selected items, their content (27 "irrational", and 10 "rational"), their extraction value, and their factor loadings in the 3 components of the initial analysis. Factor 1, which included 14 items, and Factor 3, which included 13 items, were labeled "Irrational". Factor 2, with 10 items, was labeled "Rational". Extraction values ranged from 0.4 to $0.81: 16 \%$ of them ranged between 0.4 and 0.5 , $37.8 \%$ were above 0.6 , and $45.9 \%$ were above 0.7 .

As also shown in Table 1, 32 out of the 37 items overlap with those from the original Australian study.

As shown in Table 2, Cronbach's alphas ranging between 0.74 and 0.86 indicated high internal consistency.

TABLE 1

General content and weight of the 37 items loading $58.48 \%$ of the variance, and their correspondence to those in the original Australian scale

\begin{tabular}{|c|c|c|c|c|c|}
\hline No. & Item & F- 1 & F- 2 & F-3 & Content \\
\hline$* 12$ & $\begin{array}{l}\text { If I do not satisfy the wishes of others, particularly the men in my life, it } \\
\text { would be unbearable. }\end{array}$ & 0.53 & & & Irrational \\
\hline$* 13$ & I should not try to get better pay/work conditions. & 0.71 & & & Irrational \\
\hline *16 & $\begin{array}{l}\text { It would be unbearable if I did not have someone stronger than myself to } \\
\text { rely on. }\end{array}$ & 0.67 & & & Irrational \\
\hline$* 29$ & If my children have problems it goes to show that I am a failure.. & 0.718 & & & Irrational \\
\hline$* 41$ & $\begin{array}{l}\text { It would be terrible if I did not do all I could to make myself look attracti- } \\
\text { ve. }\end{array}$ & 0.676 & & & Irrational \\
\hline$* 50$ & $\begin{array}{l}\text { It would be so uncomfortable if I challenged the decisions and advice of the } \\
\text { men in my life that I could not stand it. }\end{array}$ & 0.71 & & & Irrational \\
\hline$* 55$ & It would be awful if I did not satisfy the wishes of the men in my life. & 0.751 & & & Irrational \\
\hline *61 & $\begin{array}{l}\text { I cannot stand doing things (e.g., mathematics) that are too difficult for } \\
\text { me as a woman to understand. }\end{array}$ & 0.489 & & & Irrational \\
\hline *64 & For me to try to get better pay/work conditions would be terrible. & 0.709 & & & Irrational \\
\hline$* 69$ & I must have a husband/male partner. & 0.606 & & & Irrational \\
\hline$* 72$ & I would not be a worthwhile person if I acted assertively with men. & 0.686 & & & Irrational \\
\hline$* 76$ & It would be terrible if I put my desires or wishes first. & 0.719 & & & Irrational \\
\hline$* 82$ & $\begin{array}{l}\text { If my appearance or behavior is such that others fee inadequate around me, } \\
\text { then I am a hopeless person. }\end{array}$ & 0.712 & & & Irrational \\
\hline 86 & $\begin{array}{l}\text { It is so unpleasant if I take my work too seriously that I could not stand it if } \\
\text { I did. }\end{array}$ & 0.746 & & & Irrational \\
\hline$* 27$ & Things should go well in my family. & & 0.614 & & Rational \\
\hline$* 30$ & I could cope if I had to rock the boat and be pushy. & & 0.768 & & Rational \\
\hline 45 & $\begin{array}{l}\text { It does not mean that I am inadequate if I try hard at tasks that are too dif- } \\
\text { ficult for me as a woman. }\end{array}$ & & 0.745 & & Rational \\
\hline$* 59$ & I am still worthwhile if I push to get better pay or work conditions. & & 0.5 & & Rational \\
\hline 67 & $\begin{array}{l}\text { To challenge the decisions and advice of the men in my life might be un- } \\
\text { pleasant but it would not be a catastrophe. }\end{array}$ & & 0.615 & & Rational \\
\hline$* 74$ & It is not terrible to be assertive in front of men. & & 0.774 & & Rational \\
\hline$* 77$ & $\begin{array}{l}\text { My self worth is not dependent upon doing all I can to make myself look } \\
\text { attractive. }\end{array}$ & & 0.715 & & Rational \\
\hline
\end{tabular}




\begin{tabular}{|c|c|c|c|c|c|}
\hline No. & Item & F- 1 & F- 2 & F-3 & Content \\
\hline$* 83$ & $\begin{array}{l}\text { It would be unfortunate and disappointing if my children had problems but } \\
\text { I could stand it. }\end{array}$ & & 0.683 & & Rational \\
\hline$* 84$ & As a woman it is all right if I strive to have senior positions at work. & & 0.661 & & Rational \\
\hline *87 & $\begin{array}{l}\text { If I did not keep the house well (i.e., clean, wash, and cook) it might be } \\
\text { unpleasant but not unbearable. }\end{array}$ & & 0.655 & & Rational \\
\hline 11 & $\begin{array}{l}\text { My appearance and behavior should not be such that others feel inadequa- } \\
\text { te around me. }\end{array}$ & & & 0.492 & Irrational \\
\hline$* 15$ & I should act passively in front of men. & & & 0.686 & Irrational \\
\hline$* 26$ & As a woman it would be/is terrible to have a senior position at work. & & & 0.595 & Irrational \\
\hline$* 28$ & $\begin{array}{l}\text { If I rock the boat or I'm too pushy it would be/is the worst thing in the } \\
\text { world. }\end{array}$ & & & 0.818 & Irrational \\
\hline$* 31$ & It would be/is awful not to have a husband or male partner. & & & 0.663 & Irrational \\
\hline *34 & It would be/is unbearable not to have a husband/male partner. & & & 0.67 & Irrational \\
\hline 54 & If I put my desires or wishes first I am an unlikable person. & & & 0.717 & Irrational \\
\hline *57 & I could not tolerate having to push to get better pay or work conditions. & & & 0.722 & Irrational \\
\hline$* 63$ & $\begin{array}{l}\text { If others at work are embarrassed or upset by how much I know it goes to } \\
\text { show that I am an unlikable person. }\end{array}$ & & & 0.754 & Irrational \\
\hline *65 & I am an unlikable person if I strive for senior positions at work. & & & 0.408 & Irrational \\
\hline *71 & I must have someone stronger on whom I can rely. & & & 0.653 & Irrational \\
\hline *75 & I am a failure if I do not look after everyone else before myself. & & & 0.711 & Irrational \\
\hline *78 & It would be terrible to care for myself before every one else is taken care of. & & & 0.653 & Irrational \\
\hline
\end{tabular}

* Items coincide with those in the 64 item scale developed in the original Australian study. Source: own work.

TABLE 2

Cronbach's alpha of the Components/Factors

\begin{tabular}{lc}
\hline Factor & Cronbach's Alpha \\
\hline Factor 1. Irrationality & 0.86 \\
Factor 2. Rationality & 0.74 \\
Factor 3. Irrationality & 0.8 \\
Factor 1, Factor 3 Irrationality & 0.91 \\
\hline
\end{tabular}

Source: own work.

Since two of the components (Factor 1 and Factor 3) had "Irrationality" as content, and showed a high correlation of 0.80 between them (See Table 3), they were fused into a single factor, relabeled Factor 1: "Irrational", consisted of 27 irrational items. The Cronbach's alpha was 0.91 for the new Irrational factor. Factor 2, "Rational" consisting of 10 items, remained the same.
TABLE 3

Pearson's correlation coefficients among factors

\begin{tabular}{lccc}
\hline & Factor 1 & Factor 2 & Factor 3 \\
\hline Factor 1 & 1.0 & & \\
Factor 2 & $r=0.59^{* *}$ & 1.0 & \\
Factor 3 & $r=0.8^{* *}$ & $r=0.481^{* *}$ & 1.0 \\
\hline
\end{tabular}

*** $\mathrm{p}<0.01$.

Source: own work.

\section{Discussion and Conclusions}

The high internal consistency of each of the two components (Factor 1 and Factor 2) on the US study, in which the items accounted for $58.48 \%$ of the variance, suggests that the US version of the OWBS is a reliable instrument for the measurement of women's irrational beliefs about traditional gender roles from an REBT perspective. 
These results were consistent with an REBT model, which holds that all sources of irrationality, including the irrational thought processes of Awfulzing, Low Frustration Tolerance, and Negative Self Rating are derived from a single factor; what Ellis labeled the "musts" and "shoulds", the Demands, or rigidity in the thought process of the individual. This is empirically supported by the results of the principal components analysis of the instrument, where, regardless of their particular content, all items loaded under the "Irrational" or the "Rational" Factors.

For example, items like "I am worthless without a child" that measured Negative Self Rating and others like "It would be unbearable to act assertively in front of men" that measured Low Frustration Tolerance, still reflected the underlying rigid, absolutistic demand that it "must" or "should" happen. This tendency is not reflected on the "Rational" items like "To challenge the decisions and advice of the men in my life might be unpleasant but it would not be a catastrophe".

In addition, principal component analysis in the Australian OWBS, where the originally rational items were reversed during the scoring procedure, showed a single component labeled "General Traditional Beliefs", which accounted for $18.2 \%$ of the variance. In the US study, items were scored without reversal, and the results loaded into two Factors: Irrational vs. Rational, which accounted for $58.48 \%$ of the variance. In either case, the results of both studies support the same theoretical assumption of REBT: There is an underlying irrational, absolutistic demand at the center of an individual's dysfunctional thought process.

Equivalence in meaning and measurement of concepts between the US version and the original Australian version is further suggested by a high correspondence between 32 out of the 37 items in the former version of the OWBS and those in the latter version: An overlap of $86.49 \%$. Results to date in this preliminary study are promising suggesting that further exploration of the scale with a larger US sample would be fruitful, so valid cross-cultural comparisons in future studies could be made.

\section{References}

Bem, S. L. (1981). Bem Sex Role Inventory. Palo Alto: Consulting Psychologist Press.

Bernard, M. E. (1990, June). Validation of General Attitude and Belief Scale. Paper presented at the meeting of the World Congress on Mental Health Counselling, Keystone, Colorado, USA.

Brislin, R. (1973). Cross-cultural research methods. New York: Wiley.

Burgess, P. M. (1986). Belief systems and emotional disturbance: An evaluation of the rational-emotive model. Unpublished doctoral dissertation, University of Melbourne, Victoria, Australia.

Burgess, P. (1990). Towards resolution of conceptual issues in the assessment of belief systems in RationalEmotive Therapy. Journal of Cognitive Psychotherapy, 4, 171-184.

Campbell, I. M. (1985). The psychology of homosexuality. In A. Ellis \& M. E. Bernard (Eds.), Clinical applications of rational-emotive therapy (pp. 153-180). New York: Plenum.

Choi, N., Faqua, D., \& Newman, J. (2007). Hierarchical confirmatory factor analysis of the Bem Sex Role Inventory. Educational and Psychological Measurement, 67, 818-832.

DiGiuseppe, R., Robin, M., Leaf, R., \& Gormon, B. (1989, June-July). A discriminative-validation and factor analysis of a measure of irrational/rational beliefs. Paper presented at a poster session of the World Congress of Cognitive Therapy in Oxford, England.

Ellis, A. (1973). Humanistic Psychotherapy: The rational emotive approach. New York: McGraw-Hill.

Ellis, A. (1977). How to live with and without anger. Secaucus, NJ: Citadel Press.

Ellis, A. (1984). The essence if RET - 1984. Journal of Rational-Emotive Therapy, 2, 19-25.

Ellis, A. (1989). Comments on my critics. In M. E. Bernard \& R. DiGiuseppe (Eds.), Inside rationalemotive therapy (pp. 199-233). San Diego, CA: Academic Press.

Judd, C. M., Smith, E. R., \& Kiddler, L. M. (1991). Research methods in social relations. Orlando, Fl: Harcourt Brace Javanovich.

Larsen, K., \& Long, E. (1988). Attitudes toward sex-roles: Traditional or egalitarian? Sex Roles, 19, 1-11. 
Lega, L. I., \& Ellis, A. (2001). Rational Emotive Behavior Therapy (REBT) in the new millennium: A crosscultural approach. Journal of Rational-Emotive \& Cognitive-Behavior Therapy, 19(4), 203-224.

Locksley, A., \& Colten, M. E. (1979). Psychological androgyny: A case of mistaken identity. Journal of Personality and Social Psychology, 37, 1017-1031.

Matsumoto, D. R. (2000). Culture \& Psychology: People around the world (2nd. ed.). Stanford, CT: Wadsworth.

O'Kelly, M. (in press). Psychometric properties of the O'Kelly Women Beliefs Scale. Journal of RationalEmotive and Cognitive-Behavior Therapy.
Robin, M., DiGiuseppe, R., \& Naimark, H. (1990, August). Irrational beliefs and MCMI-2 personality disorder scores. Poster session presented at the 98th Annual Convention of the American Psychological Association, Boston, Massachusetts, USA.

Spence, J., Helmreich, R., \& Stapp, J. (1973). A short version of the Attitudes toward Women Scale (AWS). Bulletin of the Psychonomic Society, 2, 219-220.

Wolfe, J. L., \& Naimark, H. (1991). Psychological messages and social context. In M. E. Bernard (Ed.), Using rational-emotive therapy effectively (pp. 265-301). New York: Plenum. 
